\title{
STRATEGI PENGEMBANGAN RM. NASI BANCAKAN SEBAGAI DAYA TARIK WISATA KULINER DI KOTA BANDUNG
}

\author{
Rini Andari ${ }^{(1)}$ Woro Priatini ${ }^{(2)}$ Dani Ramdhani ${ }^{(3)}$ \\ Program Studi Manajemen Industri Katering. \\ Fakultas Pendidikan Ilmu Pengetahuan Sosial. \\ Universitas Pendidikan Indonesia
}

Email : dani.ramdhani2010@gmail.com

\begin{abstract}
ABSTRAK
Tren peningkatan jumlah pengunjung tiap tahun RM. Nasi Bancakan berpotensi untuk lebih berkembang, namun masalahnya daya tarik wisata rumah makan Nasi Bancakan belum begitu dikenal masyarakat luas karena pengunjung masih didominasi dari kota Bandung dan Jakarta. Dimana berpengaruh dengan persentase peningkatan jumlah pengunjung yang relatif menurun. Hasil penelitian yang dilakukan melalui analisis SWOT, yang menggunakan Matriks EFE, Matriks IFE, Matriks SWOT, dan Matriks IE.

Berdasarkan analisis SWOT dihasilkan skor total rata-rata tertimbang IFE sebesar 2,94 artinya posisi internal RM. Nasi Bancakan memiliki posisi yang kuat terhadap kekuatan dan kelemahan yang ada. Dengan skor total rata-rata tertimbang EFE sebesar 2,90 yang menunjukkan bahwa RM. Nasi Bancakan merespon dengan baik terhadap peluang dan ancaman yang ada. Strategi yang cocok diterapkan yakni strategi penetrasi pasar dan strategi pengembangan produk

Kata Kunci : Faktor Internal, Faktor Eksternal, Analisis SWOT, Wisata Kuliner, Rumah Makan Nasi Bancakan
\end{abstract}

\section{PENDAHULUAN}

\section{Latar Belakang Penelitian}

Sejak tahun 1941, kota Bandung sudah diposisikan sebagai Sentra Wisata Kuliner Nusantara karena memiliki jumlah rumah makan terbanyak diseluruh kota di Indonesia. Pendek kata, Kota Bandung adalah gudang makanan dan surga bagi kaum pengudap (tukang jajan). Kota Bandung selalu jadi trademark dan trendsetter yang cukup menawan hati dengan produk-produk kulinernya, seperti oncom, peuyeum, serabi, kacang, dan sebagainya. Bahkan tidak jarang nama Bandung dijadikan sebagai branding yang mempunyai citra bagus untuk mendongkrak penjualan (Harian Umum Pikiran Rakyat dalam Sumaryadi \& Ganef, 2010).

Dengan nilai historis tersebut maka tak heran apabila kota Bandung dijuluki sebagai surga bagi pecinta kuliner. Dengan julukan tersebut tidak membuat jumlah pengusaha jasa boga di kota Bandung berkurang. Namun sebaliknya, industri kuliner di kota Bandung semakin menggeliat. Seakan tidak ada kata habis akan kreativitas, industri ini semakin berkembang pesat. Hal ini didorong dengan jumlah pengusaha yang membuka usaha jasa boga di kota Bandung selalu bertambah setiap tahunnya.

Seperti dikutip dalam klik-galamedia.com (diakses 28 november 2013) tercatat dalam bulan Juni 2013 terdapat sekitar 3000 pengusaha Kafe dan Restoran yang 
terdata oleh Dinas Kebudayaan dan Pariwisata Kota Bandung dan baru ada sekitar 627 yang memiliki izin Kafe dan Restoran (Galamedia, 2013). Hal ini tentu saja menunjukan bahwa industri kuliner di kota Bandung memiliki potensi yang luar biasa untuk terus dikembangkan menjadi daya tarik wisata kuliner.

Atraksi wisata kuliner dewasa ini berkembang dengan gaya hidup yang memandang bahwa makanan tidak lagi hanya dinilai dari segi rasa dalam indera perasa saja, namun kini seseorang memandang makanan dilihat dari segala aspek. Penampilan dan penyajian makanan menjadi satu nilai atraksi tersendiri dalam wisata kuliner, disamping atmosper dari restoran. Wisata kuliner adalah jenis wisata yang dapat dirasakan oleh kelima indera manusia (dilihat, didengar, dicium, diraba dan dirasakan). Kesemuanya itu ber- kembang dari satu titik awal yang disebut 'makanan' (Sumaryadi \& Ganef, 2010). Menyikapi kenyataan tersebut maka peneliti tertarik untuk mengembangkan potensi daya tarik wisata kuliner yang terdapat pada Rumah Makan (RM) Nasi Bancakan untuk dikembangkan sebagai salah satu daya tarik wisata kuliner di kota Bandung. Dilihat dari tabel 1.1 yang menunjukan Data Kunjungan RM. Nasi Bancakan pada tahun 2009 - 2013.

Tabel 1.1

\section{DATA KUNJUNGAN RM. NASI}

BANCAKAN

TAHUN 2009 -2013

\begin{tabular}{|c|c|c|}
\hline Tahun & $\begin{array}{c}\text { Jumlah } \\
\text { Kunjungan }\end{array}$ & $\begin{array}{c}\text { Persentase } \\
(\boldsymbol{\%})\end{array}$ \\
\hline 2009 & 319.231 & - \\
\hline 2010 & 366.563 & 14.82 \\
\hline 2011 & 382.000 & 4.21 \\
\hline 2012 & 396.161 & 3.70 \\
\hline 2013 & 402.510 & 1.60 \\
\hline
\end{tabular}

(Sumber : Marketing RM. Nasi

\section{Bancakan, 2014)}

Tabel 1.1 menunjukan tingkat per-tumbuhan kunjungan RM. Nasi Bancakan yang tidak stabil bahkan cenderung mengalami penurunan persentase walaupun jumlah kunjungan ke RM. Nasi Bancakan terus bertambah. Dimana berdasarkan fenomena bisnis yang terjadi pada RM. Nasi Bancakan meskipun jumlah pengunjung selalu mengalami kenaikan setiap tahun, namun hal tersebut tidak sejalan dengan persentase pertumbuhan kunjungan yang mengalami penurunan tiap tahun. Fenomena diatas menunjukan bahwa RM. Nasi Bancakan mengalami depresiasi pada minat wisatawan yang turut menjadi bagian dalam pertumbuhan kunjungan.

Hal tersebut dijadikan suatu gambaran keberadaan serta keberlanjutannya sedang berada pada posisi kritis atau mature. Untuk lebih jelasnya, posisi RM. Nasi Bancakan dalam Life Cycle dapat dilihat pada gambar 1.1. 


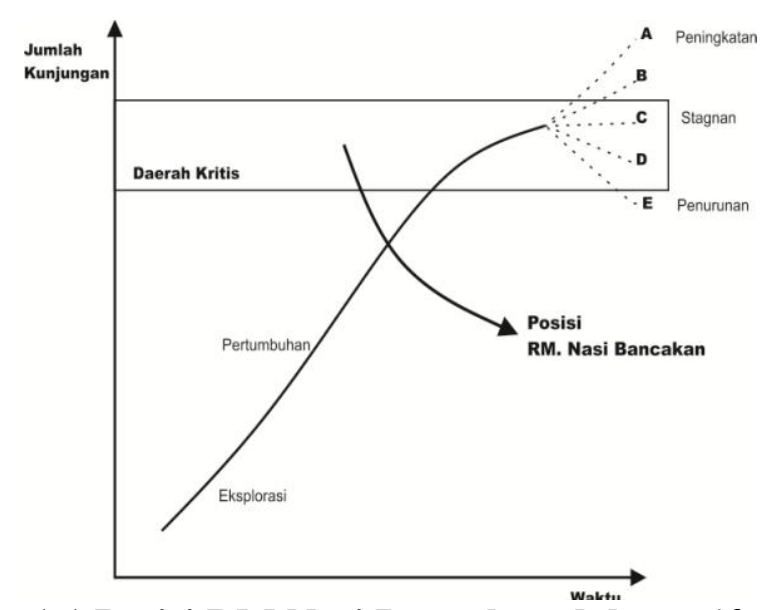

\section{Gambar 1.1 Posisi RM Nasi Bancakan dalam Life Cycle (Sumber: Peneliti, 2014 )}

Pada gambar 1.1 ditunjukan bahwa RM. Nasi Bancakan dalam posisi kritis atau mature. Maka penting, untuk RM. Nasi Bancakan melakukan strategi pengembangan guna meningkatkan jumlah kunjungan ke RM. Nasi Bancakan. Maka berdasarkan observasi pra-peneletian yang dilakukan, perlu dilakukan penelitian dengan judul: "STRATEGI PENGEMBANGAN RM. NASI BANCAKAN SEBAGAI DAYA TARIK WISATA KULINER DI KOTA BANDUNG”

\section{KAJIAN PUSTAKA}

\section{Definisi Wisata Kuliner}

Wisata Kuliner adalah kegiatan wisata yang memanfaatkan daya tarik makanan atau masakan, termasuk proses pembuatan dan budaya yang menyertainya atau gerak atau kegiatan wisata yang dimotivasi dengan wujud pada aktifitas wisatawan atau pengunjung untuk mengetahui dan menambah wawasan tentang jenis-jenis masakan dari bahan mentah menjadi bahan jadi yang siap saji (Dinas Kebudayaan dan Kepariwisataan Provinsi Jawa Barat, 2007, p. 397).Erik Wolf (World Food Travel Association, 2013) menyatakan bahwa ; "Culinary tourism is the pursuit and enjoyment of unique and memorable food and drink experiences, both far and near" dimana ditekankan wisata kuliner bukanlah suatu yang mewah dan eksklusif.

Wisata kuliner menekankan pada pengalaman bukan pada kemewahan Restoran maupun kelengkapan jenis makanan maupun minuman yang tersedia. Melihat fenomena tersebut, maka Erik Wolf menambahkan bahwa utamanya komposisi wisata kuliner. Dilihat pada tabel 2.1 Ingredients of Culinary Tourism.

\section{Tabel 2.1}

INGREDIENTS OF CULINARY TOURISM

\begin{tabular}{|l|l|}
\hline \multicolumn{1}{|c|}{ IT IS } & BUT IS NOT \\
\hline - More prepared than & - Pretentious or \\
raw materials & exclusive \\
- Consumer first - & - Only restos, food \\
farmers second & or wineries \\
- Unique \& & - Restaurant list \\
\hline
\end{tabular}




\begin{tabular}{|c|l|}
\hline Memorable & - Institutional food \\
- Locals too & services \\
& - Most chains \\
& - Recipes \\
\hline
\end{tabular}

\section{Daya Tarik Wisata Kuliner}

(Sumber : World Food Travel Association, 2013)

Daya tarik wisata kuliner dewasa ini berkembang sebagai suatu wujud penawaran akan pengalaman yang nyata. Wisata kuliner diinterpretasikan sebagai jenis wisata yang dinikmati oleh kelima panca indera manusia, yakni dengan dilihat, didengar, dicium, diraba dan dirasakan. Dimana kesemuanya itu berkembang dari satu titik awal yang disebut 'makanan'. Dalam hal ini, makanan dinilai sebagai budaya dalam pengalaman mengonsumsi, mempelajari dan pengetahuan tentang makanan, yang termasuk warisan/pusaka budaya tidak hanya yang berbentuk fisik (misalnya bangunan atau arsitektur bersejarah) dan unsur budaya atau seni (Sumaryadi \& Pah, 2010, p. 477).

Dimana saat ini wisatawan memiliki minat terhadap makanan, karena diumpamakan satu piring makanan dapat bercerita banyak. Seperti yang diumpakan BC Tourism (Sumaryadi \& Pah, 2010, p. 477) bahwa : "Every plate has a story to tell, that's what makes Culinary Tourism so special". Adapun jenis wisata kuliner yang dikemukakan oleh Sumaryadi \& Pah (2010, p. 477), antara lain ;

1) Melakukan jamuan makan di suatu tempat;

Kegiatan jamuan makan yang antara lain dilakukan di rumah makan, café, bistro, coffe shop, restaurant, dinning room, grill house, atau sejenisnya.

2) Festival-festival makanan;

Merupakan kegiatan yang bertujuan untuk promosi guna memperkenalkan makanan ke masyarakat atau wisatawan dan meningkatkan kepedulian masyarakat terhadap makanan yang sebelumnya telah dikenal.

3) Mempelajari makanan melalui sekolah atau kursus masak;

Mempelajari makanan melalui sekolah atau kursus masak dilakukan dengan tujuan memperoleh pengetahuan dan keterampilan mengenai makanan atau minuman yang diberikan oleh lembaga pelatihan atau kursus. Pada jenis aktivitas ini wisatawan atau konsumen dapat memperoleh pengalaman dengan melihat demo memasak atau bahkan berinteraksi dalam pengolahan makanan.

4) Tes makanan dan minuman;

Tes makanan atau minuman dilakukan untuk memperkenalkan dan menguji kualitas makanan kepada wisatawan atau profesional pada bidang ini. Kegiatan ini dapat berupa food test maupun wine test.

5) Mengunjungi pabrik atau industri makanan dengan menikmati olahannya;

Aktivitas jenis wisata ini bertujuan meningkatkan pengetahuan tentang bagaimana makanan diolah sambil menikmati makanan yang diolah pada pabrik atau perusahaan, misalnya hasil olahan susu, yoghurt, keju, coklat, kue, dan roti.

6) Menyaksikan kompetisi kuliner;

Aktivitas wisata ini menawarkan pengalaman untuk menyaksikan para professional atau peserta melakukan proses makanan atau minuman yang disertai atraksi dari para peserta kompetisi. 
7) Mengunjungi perkebunan dan atau perikanan sambil menikmati makanan.

Mengunjungi kawasan pertanian, perkebunan, perikanan atau budidaya bahan baku makanan lainnya dan menikmati makanan yang diolah dari bahan makanan yang dibudi-dayakan tersebut.

Dimana hakikatnya pada jenis wisata kuliner tersebut setiap hidangan yang disajikan memiliki nilai budaya, baik dari bahan baku, cara pengolahan maupun cara penyajiannya (Sumaryadi \& Pah, 2010, p. 477).

\section{METODE PENELITIAN Objek Penelitian}

Metode yang dipergunakan dalam penelitian ini adalah metode deskriptif, yaitu berusaha mendeskripsikan atau menggambarkan/ melukiskan fenomena atau hubungan antar fenomena yang diteliti secara strategis dengan sistematis, faktual dan akurat, dengan meng-gabungkan pendekatan metodologis yang bersifat analisis kualitatif dan kuantitatif melalui pendekatan komprehensif. Metode ini dipilih dengan tujuan mengumpulkan strategi stratetgis guna mengembangkan RM. Nasi Bancakan sebagai daya tarik wisata kuliner di kota Bandung.

Teknik analisis data yang dipergunakan pada penelitian ini adalah analisis SWOT. Analisis SWOT adalah alat untuk mengenali situasi, yang jika dilakukan dengan benar maka akan menghasilkan pondasi yang kuat untuk merumuskan atau memformulasikan suatu strategi (Bozac dan Tipuric dalam Hendrayana, 2011, p. 51). Analisis tersebut dipilih dengan pertimbangan dapat lebih menganalisis lebih dalam mengenai potensi, peluang, kelemahan dan ancaman yang terdapat pada RM. Nasi Bancakan. Adapun pengumpulan data dilakukan dengan pendekatan survei untuk mendapatkan data primer dan sekunder dengan teknik observasi, wawancara penyebaran kuesioner, dan studi literartur.

\section{HASIL DAN PEMBAHASAN}

\section{Analisis SWOT pada RM. Nasi Bancakan}

Berdasarkan hasil wawancara, masukan atau saran juga respon dari responden yang memberikan pendapat mengenai faktor-faktor strategis dalam pengembangan daya tarik wisata kuliner pada rumah makan Nasi Bancakan, diperoleh hasil sebagai berikut ;

a. Faktor-faktor kekuatan internal seperti:

1) Beragamnya variasi menu yang ditawarkan,

2) Daya tarik menu yang ditawarkan,

3) Teknologi tradisional dalam pengolahan makanan,

4) Daya tarik keberagaman pengolahan makanan,

5) Keunikan cita rasa, aroma dan penyajian makanan,

6) Penampilan, sikap dan keramahan staf restoran menyajikan makanan.

b. Faktor-faktor kelemahan internal adalah:

1) Manajemen operasional dapur yang tidak optimal,

2) Hygiene dan sanitasi,

3) Penguasaan bahasa asing dan hospitality skill untuk wisatawan.

c. Faktor-faktor peluang eksternal meliputi: 
1) Himbauan pemerintah untuk lebih memperkenalkan keaneka-ragaman kuliner lokal,

2) Branding kota Bandung sebagai kota tujuan wisata kuliner,

3) Berkembangnya wisata minat khusus (wisata kuliner),

4) Berkembangnya ketertarikan wisatawan terhadap makanan tradisional,

5) Sedikitnya restoran/ rumah makan yang menyajikan makanan autentik khas Sunda,

6) Akses strategis menuju Nasi Bancakan.

d. Faktor-faktor ancaman eksternal adalah:

1) Produk makanan dari daerah/negara lain,

2) Ketatnya persaingan usaha jasa boga di kota Bandung.

\section{Matriks Internal Factor Evaluation (IFE)}

Pembobotan dilakukan menggunakan metode perbandingan berpasangan (paired comparison) terhadap faktor kekuatan dan kelemahan. Rating kekuatan dan kelemahan diperoleh dari rata-rata rating yang dipilih oleh ke 30 responden untuk faktor-faktor internal tersebut. Skor faktor internal diperoleh dari perkalian antara bobot dan rating kekuatan dan kelemahan. Hasil selengkapnya seperti pada Tabel 4.1.

Tabel 4.1

Bobot, rating dan skor dari Internal Factor Evaluation - IFE

\begin{tabular}{|c|c|c|c|c|}
\hline NO & KEKUATAN & BOBOT & RATING & SKOR \\
\hline 1 & $\begin{array}{l}\text { Beragamnya variasi menu } \\
\text { yang ditawarkan }\end{array}$ & 0.12 & 3 & 0.36 \\
\hline 2 & $\begin{array}{l}\text { Daya tarik menu yang } \\
\text { ditawarkan }\end{array}$ & 0.11 & 4 & 0.44 \\
\hline 3 & $\begin{array}{l}\text { Teknologi tradisional dalam } \\
\text { pengolahan makanan, }\end{array}$ & 0.11 & 3 & 0.33 \\
\hline 4 & $\begin{array}{l}\text { Daya tarik teknologi } \\
\text { pengolahan makanan }\end{array}$ & 0.13 & 2 & 0.26 \\
\hline 5 & $\begin{array}{l}\text { Keunikan cita rasa, aroma dan } \\
\text { penyajian makanan }\end{array}$ & 0.14 & 4 & 0.56 \\
\hline 6 & $\begin{array}{l}\text { Penampilan, sikap dan } \\
\text { keramahan staf restoran } \\
\text { menyajikan makanan }\end{array}$ & 0.11 & 3 & 0.33 \\
\hline \multicolumn{5}{|c|}{ KELEMAHAN } \\
\hline 1 & $\begin{array}{l}\text { Manajemen operasional dapur } \\
\text { yang tidak optimal }\end{array}$ & 0.1 & 3 & 0.3 \\
\hline 2 & Hygiene dan sanitasi & 0.09 & 2 & 0.18 \\
\hline 3 & $\begin{array}{l}\text { Penguasaan bahasa asing dan } \\
\text { hospitality skill untuk } \\
\text { wisatawan }\end{array}$ & 0.09 & 2 & 0.18 \\
\hline & TOTAL & 1 & & 2.94 \\
\hline
\end{tabular}

(Sumber: Peneliti, 2014) 
Berdasarkan hasil tersebut, maka total skor faktor internal adalah sebesar 2,94. Dimana angka ini menunjukkan kategori kuat karena berada diatas rata-rata yaitu 2,50 (David, 2006, p. 34). Ini menunjukkan bahwa posisi internal strategi pengembangan rumah makan Nasi Bancakan dikatakan kuat sehingga mampu memanfaatkan faktor-faktor kekuatan yang ada untuk dapat mengatasi faktor-faktor kelemahannya.

\section{Matriks External Factor Evaluation (EFE)}

Pembobotan dilakukan dengan menggunakan metode perbandingan berpasangan (Paired Comparison) terhadap faktor peluang dan ancaman tersebut. Rating peluang dan ancaman diperoleh dari rata-rata rating yang dipilih oleh ke-5 responden untuk faktor-faktor eksternal. Skor faktor eksternal diperoleh dari perkalian antara bobot dengan rating peluang dan ancaman dalam pengembangan rumah makan Nasi Bancakan sebagai daya tarik wisata kuliner di kota Bandung. Hasil selengkapnya seperti pada Tabel 4.2 .

Tabel 4.2

Bobot, rating dan skor dari External Factor Evaluation - EFE

\begin{tabular}{|c|c|c|c|c|}
\hline NO & PELUANG & BOBOT & RATING & SKOR \\
\hline 1 & $\begin{array}{l}\text { Himbauan pemerintah untuk lebih } \\
\text { memperkenalkan keaneka- } \\
\text { ragaman kuliner kota Bandung }\end{array}$ & 0.14 & 3 & 0.42 \\
\hline 2 & $\begin{array}{l}\text { Branding kota Bandung sebagai } \\
\text { kota tujuan wisata kuliner }\end{array}$ & 0.13 & 3 & 0.39 \\
\hline 3 & $\begin{array}{l}\text { Berkembangnya wisata minat } \\
\text { khusus (wisata kuliner) }\end{array}$ & 0.12 & 3 & 0.36 \\
\hline 4 & $\begin{array}{l}\text { Berkembangnya ketertarikan } \\
\text { wisatawan terhadap makanan } \\
\text { tradisional }\end{array}$ & 0.12 & 4 & 0.48 \\
\hline 5 & $\begin{array}{l}\text { Sedikitnya restoran/ rumah makan } \\
\text { yang menyajikan makanan } \\
\text { autentik khas Sunda }\end{array}$ & 0.10 & 2 & 0.20 \\
\hline 6 & $\begin{array}{l}\text { Akses Strategis menuju Nasi } \\
\text { Bancakan }\end{array}$ & 0.13 & 3 & 0.39 \\
\hline \multicolumn{5}{|c|}{ ANCAMAN } \\
\hline 1 & $\begin{array}{l}\text { Produk makanan dari } \\
\text { daerah/negara lain }\end{array}$ & 0.14 & 3 & 0.42 \\
\hline 2 & $\begin{array}{l}\text { Ketatnya persaingan usaha jasa } \\
\text { boga di kota Bandung }\end{array}$ & 0.12 & 2 & 0.24 \\
\hline & TOTAL & 1.00 & & 2.90 \\
\hline
\end{tabular}

(Sumber : Peneliti,2014)

Total skor faktor eksternal sebesar 2,90. Menurut kriteria David (2006, p. 35), total skor faktor eksternal tergolong kuat karena berada diatas rata-rata 2,50. Hal tersebut menunjukkan bahwa faktor eksternal mampu memanfaatkan peluang dan menghindari ancaman.

\section{Matriks IE}


Analisis matriks IE dengan meng-gunakan dua dimensi yaitu nilai total skor faktor lingkungan internal dan nilai total skor faktor lingkungan eksternal. Matriks IE dapat menentukan strategi-strategi utama (Grand Strategy) yang merupakan strategi yang lebih detail atau lebih operasional, merupakan tindak lanjut dari strategi generik. Berdasarkan hasil analisis faktor strategis lingkungan internal dan analisis faktor strategis lingkungan eksternal diperoleh nilai total skor faktor lingkungan internal sebesar 2,94 yaitu diatas nilai rata-rata 2,50 yang berarti posisi internalnya kuat dan nilai total skor faktor eksternal sebesar 2,90 yaitu diatas nilai rata-rata 2,50 yang berarti posisi faktor eksternalnya kuat. Gambar 4.3 menunjukkan matriks posisi rumah makan Nasi Bancakan sebagai daya tarik wisata kuliner di kota Bandung.

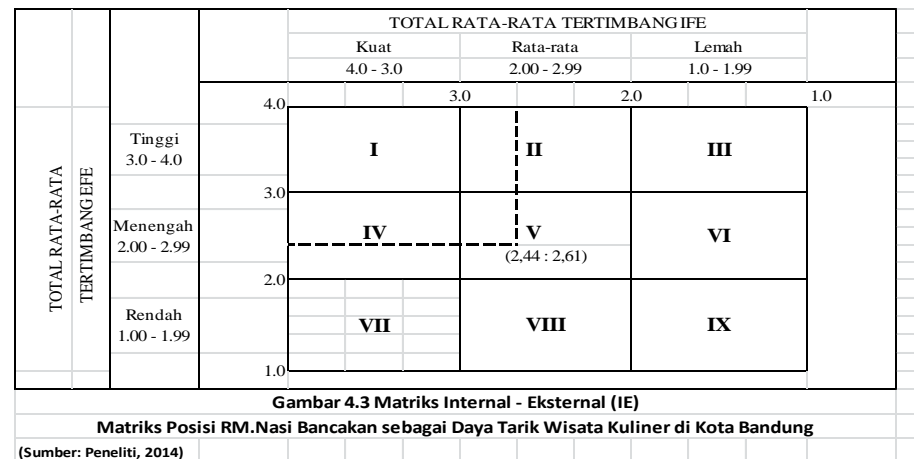

Matriks Internal-Eksternal pada Gambar 4.3 menunjukkan posisi rumah makan Nasi Bancakan sebagai daya tarik wisata kuliner di kota Bandung berada pada sel V. Karena itu, berdasarkan teori dari David (2006, p. 302) maka strategi yang seharusnya diterapkan oleh rumah makan Nasi Bancakan dalam upaya mengembangkan daya tarik wisata di kota Bandung adalah "Hold and Maintain Strategy" atau strategi "Jaga dan Pertahankan" yang terdiri dari strategi penetrasi pasar dan strategi pengembangan produk. Strategi penetrasi pasar, yaitu usaha peningkatan pangsa pasar atau market share suatu produk atau jasa yang sudah ada di pasar melalui usaha pemasaran yang lebih gencar (David, 2006). Strategi berikutnya adalah strategi pengembangan produk. Strategi pengembangan produk merupakan salah satu cara dalam meningkatan kualitas pelayanan dengan cara meningkatkan mutu produk, memodifikasikan produk-produk atau jasa-jasa yang ada sekarang atau menambah jenis produk yang baru. Strategi pengembangan produk dilakukan untuk meningkatkan daya saing.

\subsection{Pemilihan Prioritas Strategi dengan Quantitative Strategics Planning Matrix (QSPM)}

Analisis matriks QSPM bertujuan untuk menetapkan kemenarikan relatif (relative attractiveness) dari strategi-strategi yang bervariasi yang telah dipilih, dan untuk menentukan strategi mana yang dianggap paling baik untuk diimplementasikan. Matriks SWOT menghasilkan strategi-strategi alternatif yaitu:

1. Mengembangkan potensi daya tarik wisata dengan beragam jenis wisata kuliner,

2. Mempertahankan keaslian dan kualitas produk makanan khas Sunda,

3. Meningkatkan kualitas makanan tradisional khas Sunda, 
4. Meningkatkan promosi makanan tradisional Sunda,

5. Membuat standard mutu dari produk makanan lokal khas Sunda,

6. Melaksanakan pengawasan terhadap mutu produk makanan khas Sunda,

7. Memperbaiki kualitas pelayanan,

8. Meningkatkan penawaran produk makanan tradisional Sunda.

Kemudian strategi-strategi alternatif tersebut disusun dalam matriks QSPM dan pemilihan strategi didasarkan atas pandangan peneliti. Faktor yang memiliki daya tarik dari masing-masing faktor internal dan eksternal diberi nilai satu (tidak menarik) sampai empat (sangat menarik). Hasil analisis QSPM dapat dilihat pada Tabel 4.4.

Tabel 4.4

Quantitative Strategics Planning Matrix (QSPM)

Strategi Pengembangan RM. Nasi Bancakan sebagai Daya Tarik Wisata Kuliner di Kota Bandung

\begin{tabular}{|c|c|c|c|c|c|c|c|c|c|c|c|c|c|c|c|c|c|c|}
\hline \multirow{3}{*}{$\begin{array}{l}\text { FAKTOR } \\
\text { UTAMA }\end{array}$} & & \multirow{3}{*}{ Weight } & \multicolumn{16}{|c|}{ ALTERNATIF STRATEGI PENGEMBANGAN DAYA TARIK WISATA KULINER DI KOTA BANDUNG } \\
\hline & & & \multicolumn{2}{|c|}{ Strategi 1} & \multicolumn{2}{|c|}{ Strategi 2} & \multicolumn{2}{|c|}{ Strategi 3} & \multicolumn{2}{|c|}{ Strategi 4} & \multicolumn{2}{|c|}{ Strategi 5} & \multicolumn{2}{|c|}{ Strategi 6} & \multicolumn{2}{|c|}{ Strategi 7} & \multicolumn{2}{|c|}{ Strategi 8} \\
\hline & & & AS1 & TAS1 & AS2 & TAS2 & AS3 & TAS3 & AS4 & TAS4 & AS5 & TAS5 & AS6 & TAS6 & AS7 & TAS7 & AS8 & TAS8 \\
\hline \multicolumn{19}{|c|}{ Internal Factor } \\
\hline \multirow{6}{*}{ Strength } & 1 & 0.12 & 4 & 0.48 & 3 & 0.36 & 4 & 0.48 & 4 & 0.48 & 4 & 0.48 & 4 & 0.48 & 3 & 0.36 & 4 & 0.48 \\
\hline & 2 & 0.11 & 4 & 0.44 & 4 & 0.44 & 4 & 0.44 & 4 & 0.44 & 3 & 0.33 & 3 & 0.33 & 3 & 0.33 & 4 & 0.44 \\
\hline & 3 & 0.11 & 3 & 0.33 & 4 & 0.44 & 3 & 0.33 & 3 & 0.33 & 3 & 0.33 & 4 & 0.44 & 4 & 0.44 & 3 & 0.33 \\
\hline & 4 & 0.13 & 4 & 0.52 & 4 & 0.52 & 3 & 0.39 & 4 & 0.52 & 3 & 0.39 & 3 & 0.39 & 3 & 0.39 & 4 & 0.52 \\
\hline & 5 & 0.14 & 3 & 0.42 & 4 & 0.56 & 2 & 0.28 & 4 & 0.56 & 4 & 0.56 & 3 & 0.42 & 3 & 0.42 & 4 & 0.56 \\
\hline & 6 & 0.11 & 4 & 0.44 & 3 & 0.33 & 2 & 0.22 & 4 & 0.44 & 2 & 0.22 & 2 & 0.22 & 4 & 0.44 & 3 & 0.33 \\
\hline \multirow{3}{*}{ Weakness } & 1 & 0.10 & 3 & 0.3 & 2 & 0.20 & 3 & 0.30 & 2 & 0.20 & 4 & 0.40 & 4 & 0.40 & 3 & 0.30 & 3 & 0.30 \\
\hline & 2 & 0.09 & 2 & 0.18 & 2 & 0.18 & 3 & 0.27 & 3 & 0.27 & 4 & 0.36 & 4 & 0.36 & 4 & 0.36 & 4 & 0.36 \\
\hline & 3 & 0.09 & 2 & 0.18 & 1 & 0.09 & 1 & 0.09 & 2 & 0.18 & 1 & 0.09 & 1 & 0.09 & 4 & 0.36 & 2 & 0.18 \\
\hline \multicolumn{19}{|c|}{ External Factor } \\
\hline \multirow{6}{*}{ Opportunity } & 1 & 0.14 & 4 & 0.56 & 4 & 0.56 & 3 & 0.42 & 3 & 0.42 & 2 & 0.28 & 2 & 0.28 & 2 & 0.28 & 4 & 0.56 \\
\hline & 2 & 0.13 & 4 & 0.52 & 2 & 0.26 & 2 & 0.26 & 4 & 0.52 & 2 & 0.26 & 2 & 0.26 & 3 & 0.39 & 3 & 0.39 \\
\hline & 3 & 0.12 & 4 & 0.48 & 2 & 0.24 & 2 & 0.24 & 4 & 0.48 & 3 & 0.36 & 3 & 0.36 & 2 & 0.24 & 4 & 0.48 \\
\hline & 4 & 0.12 & 4 & 0.48 & 3 & 0.36 & 4 & 0.48 & 4 & 0.48 & 3 & 0.36 & 4 & 0.48 & 3 & 0.36 & 4 & 0.48 \\
\hline & 5 & 0.10 & 2 & 0.20 & 3 & 0.30 & 3 & 0.30 & 3 & 0.30 & 4 & 0.40 & 2 & 0.20 & 3 & 0.30 & 2 & 0.20 \\
\hline & 6 & 0.13 & 2 & 0.26 & 2 & 0.26 & 2 & 0.26 & 3 & 0.39 & 2 & 0.26 & 2 & 0.26 & 2 & 0.26 & 2 & 0.26 \\
\hline \multirow{2}{*}{ Threatness } & 1 & 0.14 & 2 & 0.28 & 3 & 0.42 & 4 & 0.56 & 2 & 0.28 & 2 & 0.28 & 2 & 0.28 & 2 & 0.28 & 4 & 0.56 \\
\hline & 2 & 0.12 & 2 & 0.24 & 3 & 0.36 & 4 & 0.48 & 2 & 0.24 & 2 & 0.24 & 3 & 0.36 & 4 & 0.48 & 2 & 0.24 \\
\hline \multicolumn{3}{|r|}{ TOTAL : } & & 6.31 & & 5.88 & & 5.80 & & 6.53 & & 5.60 & & 5.61 & & 5.99 & & 6.67 \\
\hline \multicolumn{3}{|r|}{ RANK : } & \multicolumn{2}{|c|}{3} & \multicolumn{2}{|c|}{5} & \multicolumn{2}{|c|}{6} & \multicolumn{2}{|c|}{2} & \multicolumn{2}{|c|}{8} & \multicolumn{2}{|c|}{7} & \multicolumn{2}{|c|}{4} & \multicolumn{2}{|c|}{1} \\
\hline
\end{tabular}

(Sumber : Peneliti, 2014)

Keterangan :

Strategi 1 Mengembangkan potensi daya tarik wisata dengan beragam jenis wisata : kuliner, 
Strategi 2 : Mempertahankan keaslian dan kualitas produk makanan khas Sunda,

Strategi 3 : Meningkatkan kualitas makanan tradisional khas Sunda,

Strategi 4 : Meningkatkan promosi makanan tradisional Sunda,

Strategi 5 : Membuat standard mutu dari produk makanan lokal khas Sunda,

Strategi 6 : Melaksanakan pengawasan terhadap mutu produk makanan khas Sunda,

Strategi 7 : Memperbaiki kualitas pelayanan,

Strategi 8 : Meningkatkan penawaran produk makanan tradisional Sunda.

Berdasarkan Tabel 4.4 diperoleh gambaran bahwa nilai TAS (Total Attractives Score) dari strategi meningkatkan penawaran produk makanan tradisional Sunda, dan meningkatkan promosi makanan tradisional Sunda, menunjukkan nilai tertinggi yang berarti bahwa strategi ini menjadi pilihan utama. Strategi mengembangkan potensi daya tarik wisata dengan beragam jenis wisata kuliner, dan memperbaiki kualitas pelayanan menjadi pilihan kedua. Strategi meningkatkan kualitas makanan tradisional khas Sunda, dan mempertahankan keaslian juga kualitas produk makanan khas Sunda, menjadi pilihan ketiga. Dan strategi membuat standard mutu dari produk makanan lokal khas Sunda, dan melaksanakan pengawasan terhadap mutu produk makasnan khas Sunda pilihan terakhir.

\section{KESIMPULAN}

Dari penelitian mengenai strategi pengembangan rumah makan Nasi Bancakan sebagai daya tarik wisata kuliner di kota Bandung, berikut adalah beberapa hal yang dapat dirangkum dalam sebuah simpulan. Adapun simpulan yang dapat ditarik dari hasil penelitian adalah sebagai berikut:

1. Berdasarkan hasil penelitian yang dilakukan, dalam pengembangannya rumah makan Nasi Bancakan memiliki kekuatan atau potensi sebagai daya tarik wisata kuliner di kota Bandung. Dimana potensi atau kekuatan yang dimiliki rumah makan Nasi Bancakan sebagai daya tarik wisata kuliner di kota Bandung secara berurutan sebagai berikut: daya tarik menu yang ditawarkan, keunikan cita rasa, aroma dan penyajian makanan, penampilan, sikap dan keramahan staf restoran menyajikan makanan, beragamnya variasi menu yang ditawarkan, teknologi tradisional dalam pengolahan makanan, dan daya tarik keberagaman pengolahan makanan. Sedangkan, faktor kelemahannya secara berurutan antara lain berikut: manajemen operasional dapur yang tidak optimal, penguasaan bahasa asing dan hospitality skill untuk wisatawan, hygiene dan sanitasi. Dimana dalam pengembangannya berdasarkan total skor yang diteliti atas hasil evaluasi faktor internal yakni kekuatan/potensi internal dan kelemahan yang dimiliki oleh rumah makan Nasi Bancakan mampu memanfaatkan faktor-faktor kekuatan yang ada untuk dapat mengatasi faktor-faktor kelemahannya. Sehingga rumah makan Nasi Bancakan berpotensi dan mempunyai potensi yang kuat sebagai daya tarik wisata kuliner di kota Bandung.

2. Dari hasil analisis yang dilakukan peneliti berdasarkan observasi dan wawancara yang dilakukan atas pengembangan rumah makan Nasi Bancakan, maka diperoleh beberapa peluang rumah makan Nasi Bancakan sebagai daya tarik wisata kuliner di kota Bandung. Dimana dihasilkan sebuah peluang dari lingkungan eksternal 
atas daya tarik wisata kuliner di kota Bandung yang merupakan peluang secara berurutan sebagai berikut: branding kota Bandung sebagai kota tujuan wisata kuliner, berkembangnya wisata minat khusus (wisata kuliner), akses strategis menuju Nasi Bancakan, himbauan pemerintah untuk lebih memperkenalkan keaneka-ragaman kuliner lokal, berkembangnya ketertarikan wisatawan terhadap makanan tradisional, dan sedikitnya restoran/ rumah makan yang menyajikan makanan autentik khas Sunda. Sedangkan faktor ancamannya secara berurutan sebagai berikut: Produk makanan dari daerah/ negara lain dan ketatnya persaingan usaha jasa boga di kota Bandung. Dengan hasil analisis yang dilakukan dengan menggunakan matriks eksternal mampu memanfaatkan peluang dan menghindari ancaman. Sehingga rumah makan Nasi Bancakan memiliki peluang yang cukup potensial untuk mengembangkan rumah makan Nasi Bancakan sebagai daya tarik wisata kuliner di kota Bandung.

3. Strategi yang relevan untuk dilaksanakan dalam rangka mendukung pengembangan rumah makan Nasi Bancakan sebagai daya tarik wisata kuliner di kota Bandung adalah:

a. Berdasarkan analisis matriks IE diperoleh strategi umum yang dapat dilaksanakan yaitu strategi penetrasi pasar dan strategi pengembangan produk. Strategi penetrasi pasar dilakukan dengan usaha peningkatan pangsa pasar atau market share produk makanan tradisional pada rumah makan Nasi Bancakan yang sudah ada melalui usaha pemasaran yang lebih gencar. Sedangkan, strategi pengembangan produk dapat dilakukan dengan cara mening-katkan mutu produk, memo-difikasikan produk-produk atau jasa-jasa yang ada sekarang atau menambah jenis produk yang baru. Strategi tersebut dapat dilakukan dengan menumbuhkan keyakinan bagi semua pihak, terutama pelaku usaha wisata yakni travel agent di kota Bandung untuk memberikan push factor (faktor pendorong) dengan membuat paket wisata kuliner dengan rumah makan Nasi Bancakan dan juga pemerintah untuk mengenalkan bahwa potensi makanan tradisional Sunda amat sangat potensial untuk dikembangkan sehingga perlu intesifikasi pemasaran melalui promosi serta menambah variasi kegiatan wisata pada makanan tradisional Sunda sehingga wisatawan merasa ingin kembali mencicipi sajian kuliner Sunda.

b. Strategi alternatif yang relevan untuk dilaksanakan pada rumah makan Nasi Bancakan sebagai daya tarik wisata kuliner di kota Bandung sebagai berikut: Strategi Strengths Opportunities (SO) adalah strategi yang menggunakan kekuatan untuk memanfaatkan peluang yang ada terdiri dari mengembangkan potensi daya tarik wisata dengan beragam jenis wisata kuliner, mempertahankan keaslian dan kualitas produk makanan khas Sunda. Strategi Strengths Threats (ST) adalah strategi yang menggunakan kekuatan untuk mengatasi ancaman terdiri dari meningkatkan kualitas makanan tradisional khas Sunda, meningkatkan promosi makanan tradisional Sunda. Strategi Weaknesses Opportunities (WO) adalah strategi meningkatkan peluang dengan menekan kelemahan yang dimiliki dengan membuat standard mutu dari produk makanan lokal khas Sunda, melaksanakan pengawas-an terhadap mutu produk makanan khas Sunda. Strategi 
Weaknesses Threats (WT) adalah strategi memperbaiki kualitas pelayanan dan meningkatkan penawaran produk makanan tradisional Sunda.

\section{DAFTAR PUSTAKA}

Adimihardja, K. (2005). Makanan dalam Khazanah Budaya. Bandung: DISBUDPAR PROPINSI JAWA BARAT \& UPT INRIK UNPAD.

Arikunto, S. (2006). Prosedur Penelitian, Suatu Pendekatan Praktik. Jakarta: Rineka Cipta.

Cresswell, J. (2002). Research Design: Qualitative and Quantitative Approaches. London: SAGE Publications.

David, F. R. (2004). Manajemen Strategis. Jakarta: PT Indeks Kelompok Gramedia.

David, F. R. (2006). Strategic Management: Concept. Jakarta: PT Salemba Empat.

Deputi Bidang Pemasaran dan Kerja Sama Luar Negeri. (2003). Penelitian Citra Pariwisata Indonesia di Mata Wisatawan Mancanegara. Jakarta: Deputi Bidang Pemasaran dan Kerja Sama Luar Negeri, Kementerian Kebudayaan dan Pariwisata.

Dinas Kebudayaan dan Kepariwisataan Provinsi Jawa Barat. (2007). Terminologi Kebudayaan dan Kepariwisataan. Bandung: Dinas Kebudayaan dan Kepariwisataan Provinsi Jawa Barat.

Fitzsimmons, J. A., \& Fitzsimmons, M. J. (2011). Service Management: Operations, Strategy, Information Technology. The McGraw-Hill.

Galamedia. (2013, July 24). Banyak Kafe dan Restoran di Bandung Tak Berizin. Retrieved November 28, 2013, from Galamedia: http://www.klikgalamedia.com/banyak-kafe-dan-restoran-di-bandung-tak-berizin

Hendrayana, M. (2011). Strategi Pengembangan Makanan Tradisional di Bali pada Hotel kawasan Sanur. Denpasar: Universitas Udayana.

Herayati, D. Y., Masnia, D. N., \& Haryanti, D. T. (1986). Makanan: Wujud Variasi dan Fungsi Serta Cara Penyajiannya Pada Orang Sunda Daerah Jawa Barat. Bandung: Departemen Pendidikan dan Kebudayaan.

Hunger, D. K., \& Wheelen, T. L. (2003). Manajemen Strategis. Yogyakarta: Andi.

Kotler, P., \& Keller, K. L. (2008). Dasar Dasar Pemasaran Edition 12nd. Jakarta: Erlangga.

Kotler, P., \& Keller, K. L. (2012). Marketing Management 14th edition. New Jersey: Pretice Hall.

Marsum, W. (2001). Restoran \& Segala Permasalahannya. Yogyakarta: Andi.

Maryam, S. (2011). Pendekatan SWOT dalam pengembangan Objek Wisata Kampoeng Djowo Sekatul Kabupaten Kendal. Semarang: Universitas Diponegoro.

McDonnel, A., \& Hall, C. M. (2008). A Framework for The Evaluation of Winery Servicescape a New Zealand Case. Journal of Tourism and Cultural Heritage, 231-247.

Leheup, R., Zakreski, E., Elenis, T., \& Jacobs, H. (2010). Ontario's Four-Year Culinary Tourism Strategy and Action Plan 2011-2015. Ontario: Ontario Culinary Tourism Alliance.

Moleong, L. J. (2010). Metodologi Penelitian Kualitatif. Bandung: Rosda Karya. 
Nilasari, S. (2014). Manajemen Strategi itu Gampang. Jakarta: Dunia Cerdas.

Nugraha, R., Mulyadi, H. H., \& Setiyorini, H. D. (2013). Pengaruh Produk Wisata terhadap Keputusan Berkunjung Wisatawan pada Daya Tarik Wisata Waduk Darma Kabupaten Kuningan. Tourism and Hospitality Essentials Anthology (The Anthology), Edisi I, 1-17.

Nurchalis. (2011). Pelestarian Keraton Alwatzikhoebillah sebagai Daya Tarik Wisata Sejarah di Sambas Kalimantan Barat. Denpasar: Universitas Udayana.

Oda. (2012). Pengembangan Pusat Kuliner Nusantara Kota Bandung Sebagai Tujuan Wisata. Khasanah Ilmu - Jurnal Pariwisata dan Budaya.

Pah, J. G. (2013). Makanan dan Minuman sebagai Atraksi Wisata. International Seminar Gastronomy. Bandung: Indonesia University of Education.

Parma, I. P. (2012). Formulasi Pengembangan Masakan Lokal Sebagai Produk Wisata Kuliner di Kabupaten Buleleng. Denpasar: Universitas Udayana.

Pendit, I. N. (2002). Ilmu Pariwisata Sebuah Pengantar Perdana. Jakarta: PT. Pradnya Paramita.

Permana, T. S. (2011). Makanan Tradisional Sebagai Daya Tarik Wisata Kuliner di Kota Medan. Medan: USU Repository.

Pitana, I. G., \& Diarta, I. k. (2009). Pengantar Ilmu Pariwisata. Yogyakarta: Andi.

Primadany, S. R., Mardiyono, \& Riyanto. (2013). Analisis Strategi Pengembangan Pariwisata Daerah. Jurnal Administrasi Publik (JAP), Vol. 1, No. 4, 135-143.

Priyatno, D. (2009). Mandiri Belajar SPSS. Yogyakarta: Mediakom.

Putri, T. A. (2014, March 17). Pariwisata Sumbang Devisa US\$ 10 Miliar . Retrieved April 8, 2014, from Tempo.co: http://www.tempo.co/read/news/2014/03/17/090562890/Pariwisata-SumbangDevisa-US-10-Miliar-

Rangkuti, F. (2006). Analisis SWOT: Teknik Membedah Kasus Bisnis-Reorientasi Konsep Perencanaan Strategis untuk Menghadapi Abad 21. Cetakan ke-14. Jakarta: Gramedia Pustaka Utama.

Reid, D., \& Bojanic, C. (2006). Marketing for Hospitality and Tourism. Second Edition. Prentice Hall International, Inc.

Solihin, I. (2012). manajemen strategik. Jakarta: Erlangga.

Sugiyono. ( 2005). Metode Penelitian Kualitatif. Bandung: Alfhabeta.

Sugiyono. (2008). Metode Penelitian Bisnis. Bandung: Alfhabeta.

Sumaryadi, \& Ganef. (2010). Kajian Wisata Kuliner Kota Bandung. Jurnal Kepariwisataan Indonesia, 473.

Suriani, N. M. (2009). Seni Kuliner Bali Sebagai Salah Satu Daya Tarik Wisata Studi Kasus Di Warung Babi Guling Ibu Oka Di Kelurahan Ubud, Gianyar, Bali. Program Studi Magister (S2) Kajian Pariwisata. (Thesis). Denpasar: Universitas Udayana.

Sutopo, H. B. (2006). Penelitian Kualitatif : Dasar Teori dan Terapannya Dalam Penelitian. Surakarta: Universitas Sebelas Maret. David, F. R. (2006). Strategic Management: Concept. Jakarta: PT Salemba Empat.

Suwantoro, G. (2004). Dasar-Dasar Pariwisata. Yogyakarta: Andi.

Tjiptono, F. (2011). Pemasaran Jasa. Bayu Media. 
Tobing, I. A. (2009). Peranan Makanan Tradisional Dalam Pengembangan Wisata Kuliner di Kota Medan. Medan: USU Repository.

Warpani, S. P., \& Indira. (2007). Pariwisata dalam Tata Ruang Wilayah. Bandung: Institut Teknologi Bandung.

World Food Travel Association. (2013). What Is Food Tourism? Retrieved May 14, 2014, from World Food Travel Association: http://www.worldfoodtravel.org/what-is-food-tourism/

Yazid. (2008). Pemasaran Jasa Konsep dan Implementasi. Yogyakarta: CV. Adipura.

Yoeti, O. A. (2008). Perencanaan dan Pengembangan Pariwisata. Jakarta: Pradnya Paramita .

Zeithaml, Valerie, Bitner, M. J., \& Dwayne. (2011). Service Marketing. Mc Graw Hill. 